\title{
The impact of bank lending on Palestine economic growth: an econometric analysis of time series data
}

\author{
Ibrahim M. Awad ${ }^{1 *}$ and Mohammed S. Al Karaki ${ }^{2}$
}

\author{
* Correspondence: iawad@staff. \\ alquds.edu; iawad00@gmail.com; \\ http://erf.org.eg/affiliates/ibrahim- \\ awad/ \\ ${ }^{1}$ Faculty of Business and Economics, \\ Al-Quds University - Abu Dis \\ Campus, P. O. Box 51000, Jerusalem, \\ Palestine \\ Full list of author information is \\ available at the end of the article
}

\begin{abstract}
Banking is an essential sector of Palestine's economy. More credits provided by banks are considered to have a positive impact on economic growth so that the overall objective of this study is to examine the impact of bank lending on economic growth in Palestine. The study employs the Augmented Dickey-Fuller to test for stationarity in the time series, The Johansen co-integration, Vector Autoregressive Model and Vector Error Correction Model are employed to identify the long-run and short-run dynamics among the variables, and Granger causality test in order to determine the direction of causality. The study finds that a long run relationship exists among the variables and insignificant short run relationship. Also, the study findings show that there is unidirectional causality and runs from GDP to bank lending. The insignificant contribution of bank lending to GDP is attributed to the fact that banks are not highly interested in lending to the production sector of the economy due to the high level of risk. However, the primary empirical evidence reveals that bank lending doesn't cause economic growth, but economic growth causes bank lending.
\end{abstract}

Keywords: Economic growth, Error correction model, Bank lending, Granger causality test, Palestine, Unit root tests, Solow growth model

\section{Introduction}

The modern economy is a credit economy. The economy requires credit for different purposes; one main purpose is to promote economic activities (Nwaru and Okorontah 2014). Credit fuels economic activities by allowing businesses to invest beyond their cash on hand, households to purchase homes without saving the entire cost in advance, and governments to smooth out their spending by mitigating the cyclical pattern of tax revenues and in investing in infrastructure projects. The influence of credit on economic growth has been widely debated in economic literature over the last decades. Therefore, he goes to a moneylender to borrow the cash under his friend's guarantee. The moneylender, Shylock, demands a pound of flesh as security if the money is not paid back. Accordingly, paying more attention to uncertainty and risk is necessary to be taken into account (Awad and Al-Ewesat 2017). Furthermore, the more you grow, the more you become powerful. The earliest Italian banks adapted this thought; the Medici Bank, which had multiple relevant partnerships moved from

(c) The Author(s). 2019 Open Access This article is distributed under the terms of the Creative Commons Attribution 4.0 International License (http://creativecommons.org/licenses/by/4.0/), which permits unrestricted use, distribution, and reproduction in any medium, provided you give appropriate credit to the original author(s) and the source, provide a link to the Creative Commons license, and indicate if changes were made. 
financial success to hereditary status and power. The Medici Bank achieved this by adapting the risk diversification and by engaging in currency trading as well as lending. As a result, they reduced their vulnerability to defaults (Ferguson 2008).

Banking activity is confirmed to be a significant factor in driving local economic growth, in line with the empirical literature on the relationship between finance and economic growth (Caporalea et al. 2016). In line with this, bank lending in the euro area has continued to expand. In 2017, loans to households grew by $2.8 \%$ and loans to non-financial corporations by $2.9 \%$ (European Economic Forecast Winter 2018). However, the link between bank lending and economic growth has important policy implications for development strategies. Especially, in the field of increasing the rate of economic growth in spite of the limited role of the banking sector to control the money supply and its effects on the economy. Therefore, the statement of problem measures "The impact of bank lending on the economic growth in Palestine during the period from 1996 to 2015".

The primary goal of the study is to examine the impact of bank lending on economic growth in Palestine. The specific objectives are to (1) Investigate whether it is possible to use bank lending as the means of long-term economic growth, and if so, under which conditions; (2) Understand the relationship between bank lending and economic growth with other economic indicators; and (3) Apply Granger causality test to examine the causal relationships between the examined variables.

\section{Palestinian economy and banking system}

Palestine is a developing country with an emerging economy characterized by some features that distinguish it from other economies. One of these features is the absence of local currency and the use of the three major currencies US dollar, the Jordanian dinar and the Israeli Shekel. In addition to these features the Palestinian economy dependent on foreign aids and characterized as a service economy. Added to that, in Palestine, there is no a good policy adopted by Palestinian policymakers to direct resources continuously from unproductive sectors to productive ones that can reduce the unemployment rate, and increase aggregate demand and GDP growth in the long run (Awad et al. 2017).

The total Palestinian GDP was about 7000 million dollars in 2015, and the annual real GDP growth rate showed visible fluctuations during 1996-2015 due to the political conditions. Real GDP growth rate was the highest (13.7\%) in 1997 due to the relative political stability during that year; period from 2000 to 2002 and year 2006 witnessed the lowest growth rate (Palestine Monetary Authority (PMA), P. M 2016).

In general, the average annual real GDP growth rate reached 4.7\% during (1996-2015), which is not sufficient to enable the Palestinian economy to enter into the process of self-growth and achieve sustainable development. In addition, real GDP per capita rate reached 1.6\% during (1996-2015) (Palestine Monetary Authority (PMA), P. M 2016).

As shown in the Table 1, the banking system in Palestine consists of 17 banks with 232 branches and offices 7 of them are local banks, and 9 are Arab banks, and one is a foreign bank. The number of commercial banks is 15 banks and 2 Islamic banks. Total Bank Lending and deposits of residents have grown substantially in the last few years, from $\$ 423$ million Bank Lending and $\$ 1707.5$ billion deposits of residents at the end of 1996 to $\$ 4.480$ billion Bank Lending and $\$ 8024$ billion deposits of residents at the end 
Table 1 The Palestinian Banking System Institutions (PMA, 2014)

\begin{tabular}{llllll}
\hline \multicolumn{2}{l}{ Palestinian Banking System Institutions (PMA,2014) } & & & \\
\hline Foreign Banks & & & & Local Banks \\
\cline { 1 - 2 } Name of bank & Since & & & Name of bank & Since \\
\hline Cairo Amman Bank & 1986 & & Bank of Palestine P.L.C & 1960 \\
Arab Bank & 1994 & & Palestine Commercial Bank & 1994 \\
Bank of Jordan & 1994 & & Palestine Investment Bank & 1995 \\
Egyptian Arab Land Bank & 1994 & & Arab Islamic Bank & 1995 \\
Jordan Commercial Bank & 1994 & & Palestine Islamic Bank & 1995 \\
Jordan Ahli Bank & 1995 & & Al Quds Bank & 2005 \\
Housing Bank for Trade \& Finance & 1995 & & The National Bank & \\
Jordan Kuwait Bank & 1995 & & & \\
Union Bank & 1995 & & & \\
HSBC Bank Middle East Limited & 1998 & &
\end{tabular}

of 2015. The Palestine Monetary Authority (PMA) monitors the banking sector closely to assist the expansion (Palestine Monetary Authority (PMA), P. M 2016). Given this, the variable bank lending is taken into account as an independent variable in the model of the study.

\section{Economic growth}

Economic growth is a sustained expansion of production possibilities measured as the increase in real GDP over a given period (Slavin 2009, p. 390). Alternative theories of economic growth of classical growth theory, neoclassical growth theory, and new growth theory provide insights into the process of economic growth, but none provides a complete and definite answer to the fundamental questions: What causes economic growth and why do growth rates vary? Why are poor countries poor? How design policies that can help them grow? How our own growth rate is affected by shocks and our government's policies? Economics has some way to go before it can provide definite answers to these questions. The growth theories have developed over time, each building upon and replacing the previous theory (Parkin 2012, p. 37). Accordingly, the variable economic growth is considered as a dependent variable in this study.

\section{Schumpeter's view}

Schumpeter made the first articulated statement about how financial transactions take an essential stage in economic growth. It is necessarily a phenomenon of development, though only when no central authority directs the social process. He makes possible the carrying out of new combinations, authorises people, in the name of the society as it were, to form them (Schumpeter 1939, p. 1-20).

\section{The Solow growth model}

Solow's theory on growth supports the neoclassical view that the economy naturally adjusts to achieve stable equilibrium growth. Before the Solow model, the most commonly referred to model in growth is Harrod-Domar, which mostly focuses on the 
potential shortcomings of growth such as the coexistence of growth and increasing unemployment.

We assume that the economy produces a single good Yt by means of two factors of production - capital, Kt and labour, Lt. The production function:

$$
\mathrm{Yt}=\mathrm{F}(\mathrm{Kt}, \mathrm{At}, \mathrm{Lt})
$$

The Solow growth model is designed to show how growth in the capital stock, growth in the labour force, and advances in technology interact in an economy, and how they affect a nation's total output of goods and services. To meet the overall objective of this study, the Solow growth model is adopted for examining the impact of Gross Capital Formation, labour, and bank lending on economic growth.

\section{Literature review}

The impact of bank lending on economic growth is a controversial issue on both empirical and theoretical framework, the theoretical underpinnings of this relationship can be found in the works of Schumpeter (1954), p. 111) and more recently in the works of McKinnon (1973), Shaw (1973) and Lucas (1988). This controversial economic issue is still a research gap in Palestine so that this empirical study focuses on examining the impact of bank lending on economic growth using economic analysis of time series data.

On the other hand, Banu (Butiuc) and Mădălina (2013) observed that credits offered to households contribute to a greater extent to the formation of the GDP than credits offered to the public. Precious and Palesa (2014) explore the role played by monetary policy in promoting economic growth in the South African economy over the period 2000-2010. Accordingly, the long and short run causal relationships between economic growth, financial depth and lending rate in the unique economic setup of Saudi Arabia where 92\% of total GDP comes from oil exports (Nasir et al. 2014). Aliero (2013) explores the relationship between private sector credit and economic growth in Nigeria, using time series data over the period of thirty-seven (37) years (1974-2010). However, causality results indicate that there is no causal relationship between the private sector and economic growth in Nigeria. Ekone (2010) revealed that although money supply is positively related to growth, the result is however insignificant in the case of GDP growth rates on the choice between contractionary and expansionary money supply.

On the other hand, Nwaru and Okorontah (2014) observed that real output causes financial development, but not vice versa, and that export was not significant in driving financial development, but growth in the financial sector was highly dependent on foreign capital inflows. Additionally, the MDGP and banking sector reforms indicators (BF) move differently with one not predicting the other within the study period, and there is a causal effect from manufacturing output growth to banking development or a bi-directional relationship (Owolabi et al. 2013), and (Ndlovu 2013) reveal that there is unidirectional causality from economic growth to financial development. Financial system development is, therefore, an outcome of the pressure for institutional development in capital markets and the introduction of modernized financial instruments. Smith (2012) provides some preliminary but consistent evidence that there is a causal impact of remittance flow on banking sector development in Fiji. Simwaka (2012) finds that Granger causality tests results show that economic growth drives financial 
development with no feedback effects. Liang and Huang (2011) shows that The Granger Causality result shows that d(M2) does not Granger Cause d (GDP), and d (GDP) Granger Cause d(M2). The bank credit affects real GDP per worker through its role of domestic capital accumulation and efficient resource allocation (efficiency) and hence, in total factor productivity in the long-run (Murty et al. 2012). Accordingly, a pro-active policy of growth and reform of the financial sector will help enhance economic growth in an open developing economy like Saudi Arabia (Masih et al. 2010). In addition, the efficient development of modern banking sector of bank lending is a useful instrument to promote economic growth in Nepal (Timsina and Pradhan 2016).

With regards to the bi-directional causality, (Fosu 2013) provides evidence that there exist bidirectional causality between financial development and growth. Yazdi and Khanalizadeh (2013) suggest that there is bidirectional causality between agricultural economic growth and financial development. Guttentag (2011) shows that the existence of a stable long-run relationship between financial development measures and economic growth. Results show different causality patterns between the two models. Jordaan (2010) finds that evidence of supply-leading and demand-leading views. When the ratio of deposit liabilities to non-mineral GDP is used as a proxy for financial development, the causality runs from financial development to economic growth, which supports Schumpeter's supply-leading view. Egbetunde and Akinlo (2010) show the need to develop the financial sector through appropriate regulatory and macroeconomic policies.

With reference to negative causality, the relationship between financial sector development and economic growth, using a sample of northern and southern Mediterranean countries (Algeria, Egypt, Israel, Jordan, Lebanon, and Libya, Morocco, Palestine, Syria, Tunisia, and Turkey) during the years 1985-2009 (Ben-Naceur et al. 2013). The results on the large sample indicate that credit to the private sector and bank deposits are in many specifications negatively associated with growth, meaning that there are problems of credit allocation in the region and weak financial regulation and supervision. Maduka and Onwuka (2013) concluded that: (1) increase nonperforming loans and interest rate spreads negatively affect economic growth, (2) increase in domestic credit to private sector negatively affect GDP growth, but increase its growth rate positively affects GDP (3) broad money growth is less relevant for economic growth. However, the impact of banking intermediation on the economic growth in ten countries in the MENA region over the period 1990-2009 using the method of GMM estimation for dynamic panels (Taha et al. 2013). Given this literature review, examining the interrelationship between bank lending and economic growth is likely to provide policymakers with valuable information and policy recommendations for enhanced economic growth in Palestine. Also, this empirical study will provide researchers with background information for future research.

\section{Research methodology}

In context of this study, we used quarterly time series data for examining the impact of bank lending on the economic growth in Palestine during the period from 1996 to 2015 by using the production function model and adapt it with Schumpeter's view as shown before, this time period is the only available data on the study variables, especially the Palestinian Authority (PA) was established in 1994 as an outcome of the Oslo peace process. The whole available time period was adopted to meet the study 
objectives and provide policymakers with background information on how bank lending drives economic growth in Palestine. The relationship between bank lending and economic growth has important policy implications for development strategies in Palestine. Especially in the field of increasing the rate of economic growth in spite of the limited role of the banking sector to control the money supply and its effects on the economy.

A set of econometrics procedures and the test will be applied by using Eviews 7 software. These tests are time series analysis procedures: the unit root test of variables, Cointegration Tests, Lag Order Selection, VAR model estimation, VECM procedures, Wald Test, diagnostic tests and the Granger causality test. The variables used in this study are quarterly data. The period of study covering from 1996 to 2015 includes 80 observations.

\section{Methodology}

This study intends to examine the impact on bank lending on economic growth during the period from Q1 1996 to Q4 2015. The model equation will be as the following:

$$
\log \left(G D P_{t}\right)=\beta_{1} \log \left(K_{t}\right)+\beta_{2} \log \left(L_{t}\right)+\beta_{3} \log \left(B L_{t}\right)+\varepsilon_{t}
$$

Or

Where:

$\log \left(G D P_{t}\right)$ : The natural logarithm of the real GDP

$\log \left(K_{t}\right)$ : The natural logarithm of the Gross Capital Formation.

$\log \left(L_{t}\right)$ : The natural logarithm of the percentage Labour.

$\log \left(B L_{t}\right)$ : The natural logarithm of Bank Lending.

Also, we will test the hypothesis of a causal relationship between both Private and Public Bank Loans and GDP. The models will be as the following:

$$
\begin{aligned}
& \log \left(G D P_{t}\right)=\beta_{1} \log \left(K_{t}\right)+\beta_{2} \log \left(L_{t}\right)+\beta_{3} \log \left(\text { Private } B L_{t}\right)+\varepsilon_{t} \\
& \log \left(G D P_{t}\right)=\beta_{1} \log \left(K_{t}\right)+\beta_{2} \log \left(L_{t}\right)+\beta_{3} \log \left(\text { Public } B L_{t}\right)+\varepsilon_{t}
\end{aligned}
$$

Since time series variables usually exhibit non-stationary, and their linear combination can be stationary, we first subject each series to the standard unit root and cointegration tests. In the study, we apply the widely used augmented Dickey-Fuller (ADF) unit root test to determine the variables' stationarity properties or integration orders. To see whether they share a common path over the long run, i.e. whether they are cointegrated, we adopt a VAR-based cointegration test as suggested by Johansen (1988) and Johansen and Juselius (1990). With the finding of cointegration, we first estimate their long-run relation. Then, the dynamic interactions among the variables are evaluated using the vector error-correction model (VECM). Apart from the Granger causality tests, we also simulate impulse-response functions to assess the variables' dynamic interactions further.

\section{Stationarity test (unit root test)}

In order to determine the relationship unit root tests are essential in detecting the stationary behaviour of a time series data. If the data is non-stationary after first difference, it means that the data follows a random walk and according to the Gauss-Markov 
theorem the series will not have a finite variance. This study used a test of unit root on the time series data which is the Augmented Dickey-Fuller test (ADF).

While the equation with trend and intercept is as under:

$$
\Delta X_{t}=\beta_{0}+\beta_{1} t+\beta_{2} X_{t-1}+\sum_{i=1}^{k-1} \beta_{i} \Delta X_{t-i}+\varepsilon_{t}
$$

The model the Null and Alternative hypothesis is given as under,

\section{HO: $\beta 2=0$ Data is Non Stationary}

$\mathrm{H} 1: \beta 2<0$ Data is Stationary

The H0 hypothesis has a unit root that means that data is non-stationary and H1 hypothesis do not contain a unit root, so data is stationary. We can find two motives behind unit root tests. The first knows the order of integration is crucial for setting up an econometric model and do inference. The second motive is that economic theory suggests that certain variables should be integrated a random walk or a martingale process.

\section{Lag order selection criteria}

The second step involves the determination of lag lengths to be included in the cointegration test and subsequent VECM. The choice of lag length is determined by using the Akaike information criterion (AIC). This was used to determine the appropriate lag length in the Granger causality test where the number of augmenting lags (p) was determined by minimizing the Akaike information criterion where lags are dropped until the last lag is statistically significant (Awe 2012).

\section{Test for co-integration}

When the issue of the unit root has been established, the co-integration test shall be applied. Granger (1981) theory of cointegration extended by Engle and Granger (1987) examines the long run relation by co integrating short term and long term relationship. If co-integration exists, that would mean that there is a long run linear relationship among variables. This study uses a multivariate co-integration method by Johansen and Juselius (1990). Some of the advantages of the Johansen's procedure are: (1) it can estimate more than one cointegration relationship, if the data set contains two or more time series; (2) it permits the testing of cointegration as a system of equations in one step; (3) do not carry over an error from one step into the rest; and it does not require the prior assumption of endogeneity or exogeneity of the variables (Bashir 2003); (4) Gonzalo (1994) concludes that Johansen's approach performs better than the other approaches even when the errors are not normally distributed, or the dynamics of the VECM are unknown, and additional lags are included in the VECM; and (5) Hargreaves (1994) concludes that Johansen's method is the best if the sample size is relatively large.

This method tests the long term relationship among the non-stationary variables and hence tells the number of co-integrating vectors among the variables under study. Johansen test produces two types of statistical results; the first one is Unrestricted Co-integration Rank Test (Trace) and the second is Unrestricted Co-integration Rank Test (Maximum Eigenvalue). Trace test with $\mathrm{HO}$ that there is at most "S" co-integrated 
equations and $\mathrm{H} 1$ that there is " $\mathrm{S}$ " or more co-integrating vectors. The other is MaxEigen statistics with $\mathrm{H} 0$ that there exist " $\mathrm{x}$ " co-integrating vectors against H1hypothesis of $x+1$ co-integrating vectors. Johansen co-integration is sensitive towards lag length selection, so this study uses optimum lag length. Johansen's methodology takes its starting point in the vector autoregression (VAR) of order $p$ given by:

$$
\Delta X_{t}=\beta_{1} \Delta X_{t-1}+\ldots+\beta_{p-1} \Delta X_{t-p-1}+\beta_{p} X_{t-1}+\varepsilon_{t}
$$

The study has made decisions on the primary results of trace statistic and Maxeigen values obtained from applying Johansen cointegration test.

We adopt, in this study, Johansen and Jueslius approach as in the following studies: (Nasir et al. 2014), (Precious and Palesa 2014), (Maduka and Onwuka 2013), (Murty et al. 2012), (Masih et al. 2010), (Yazdi and Khanalizadeh 2013), (Jordaan 2010), (Egbetunde and Akinlo 2010), (Ndlovu 2013), and (Carby et al. 2012).

\section{The vector autoregressive (VAR) model}

The vector autoregressive (VAR) model as considered in this study is:

$$
Y_{t}=A_{1} Y_{t-1}+A_{2} Y_{t-2}+\ldots+A_{p} Y_{t-p}+\varepsilon_{t}
$$

$$
\text { Where } Y_{t}=\left[\begin{array}{c}
\log \left(G D P_{t}\right) \\
\log \left(K_{t}\right) \\
\log \left(L_{t}\right) \\
\log \left(B L_{t}\right)
\end{array}\right] \text { is a k-vector of non stationary I(1) endogenous variables }
$$

(here $\mathrm{k}=4), A_{1}, A_{2}, \ldots, A_{p}$ are matrices of coefficients to be estimated and $\varepsilon_{t}$ is a vector of innovations that may be contemporaneously correlated but are uncorrelated with their own lagged values and uncorrelated with all of the right hand side variables.

\section{Vector error correction model (VECM)}

The VECM technique rectifies to both short term variations in variables and divergences from equilibrium. The following is the general equation of VECM:

$$
\begin{aligned}
\Delta G D P_{t}= & \beta_{0} E C T+\sum_{i=1}^{p-1} \beta_{1 i} \Delta G D P_{t-i}+\sum_{i=1}^{p-1} \beta_{2 i} \Delta K_{t-i}+\sum_{i=1}^{p-1} \beta_{3 i} \Delta L_{t-i} \\
& +\sum_{i=1}^{k-1} \beta_{4 i} \Delta B L_{t-i}+\varepsilon_{t}
\end{aligned}
$$

Where $\mathrm{p}$ is the optimum lag number, and ECT is the error correction term. If the coefficient $\left(\beta_{0}\right)$ of the ECT is negative and significant at the same time, then we can find the adjustment speed or the speed to reach the equilibrium, and we can emphasize causality in the long run, then using the Wald test we can determine the significance of explanatory variables to emphasize causality in the short run in the statistical model. The study has used the Wald test is to determine the significance of explanatory variables in the statistical model.

\section{Granger causality test}

Granger causality may have more to do with prediction, than with causation in the usual sense. It suggests that while the past can cause/predict the future, the future 
cannot cause/predict the past. X Granger causes $\mathrm{Y}$ if the past values of $\mathrm{X}$ can be used to predict $\mathrm{Y}$ more accurately than just using the past values of $\mathrm{Y}$.

The traditional Granger test for testing causality between Bank Loans (BL) and economic growth (GDP) can be represented as follows:

$$
\begin{aligned}
& G D P_{t}=\sum_{i=1}^{p} \beta_{i} B L_{t-i}+\sum_{i=1}^{p} \lambda_{i} G D P_{t-i}+\delta_{t} \\
& B L_{t}=\sum_{i=1}^{p} \mu_{i} B L_{t-i}+\sum_{i=1}^{p} \theta_{i} G D P_{t-i}+\varepsilon_{t}
\end{aligned}
$$

Where $\delta_{t}$ and $\varepsilon_{t}$ are uncorrelated.

\section{Definition of variables}

In this section, we define the study variables as used in the analysis.

\section{Economic growth}

As a dependent variable, real annual GDP of Palestine over the period of 1996 to 2015 was considered, according to the definition of Palestinian Central Bureau of Statistics (PCBS) (2016), Gross Domestic Product or GDP is intended to be a measure of the value created by the productive activity of resident institutional units during a certain period in time. Estimate of GDP, like the output and the value added, can vary according to taxes and subsidies are taken into consideration. GDP is usually estimated at market prices, producers' prices, or basic prices. There are three approaches to estimate the GDP: Output or Production approach, Expenditure approach, and Income approach.

\section{Bank lending}

Annual Bank Lending in Palestine as an independent variable over the period of 1996 to 2015 was taken. Distribution of bank lending by economic activities is not the same over the period of study. Over the period from 1996 to 2007, bank lending was distributed in two main categories (bank lending for public sector and bank lending for private sector which includes 11 economic activities) on the other hand bank lending distributed over the rest of study period by different economic activities (bank lending for public sector and bank lending for private sector which includes 14 economic activities) as shown in Table 2 below:

\begin{tabular}{|c|c|c|c|c|c|c|}
\hline \multirow[t]{3}{*}{ Series } & \multicolumn{3}{|c|}{ 0:unit roots (1) } & \multicolumn{3}{|c|}{ 0:unit roots $\quad(0)$} \\
\hline & \multicolumn{3}{|l|}{ Log level } & \multicolumn{3}{|l|}{ First difference } \\
\hline & Test statistics & Critical value & $p$-value & Test statistics & Critical value & $p$-value \\
\hline GDP & 0.854145 & -1.945823 & 0.8923 & -2.228159 & -1.945823 & 0.0260 \\
\hline TOTALBL & 1.298411 & -1.945525 & 0.9497 & -2.620761 & -1.945525 & 0.0094 \\
\hline K & 0.553814 & -1.945823 & 0.8333 & -2.763163 & -1.945823 & 0.0064 \\
\hline L & -0.153110 & -1.945823 & 0.6271 & -2.358341 & -1.945823 & 0.0188 \\
\hline Private BL & 1.552725 & -1.945823 & 0.9694 & -2.325434 & -1.945823 & 0.0204 \\
\hline Public BL & 1.052878 & -1.946161 & 0.9219 & -2.895378 & -1.946161 & 0.0044 \\
\hline
\end{tabular}

Table 2 Unit Root Test 


\section{Labour}

In this study, we will focus on Employment as an indicator for Labour Force in Palestine which is defined by PCBS: Persons in employment comprise all persons above a specified age who during a specified brief period, either 1 week or 1 day, were in the following categories: paid employment; self-employment. According to this definition employment in percentage over the period (1996-2015) was adopted as an independent. According to the definition of PCBS: Labour Force Survey (2014), Persons aged 15 years and over who were at work at least $1 \mathrm{~h}$ during the reference period, or who were not at work during the reference period, but held a job or owned business from which they were temporarily absent (Palestinian Central Bureau of Statistics (PCBS) 2016).

\section{Gross capital formation}

Gross Capital Formation over the period of 1996-2015 was considered as an independent variable. According to the definition of Palestinian Central Bureau of Statistics (PCBS) (2016), gross capital formation is the total value of producers acquisitions fewer disposals of fixed asset during the accounting period plus specific addition to the value of non-produced assets released by the productive activity of institutional units, fixed assets are tangible or intangible assets produced as from process of production that is themselves used repeatedly or continuously in another process of production for more than 1 year.

\section{Empirical results}

This critical section will introduce the empirical results of the study variables defined above. We used time series analysis procedures: the unit root test of variables, Cointegration Tests, VAR model estimation, Lag Order Selection, VECM procedures with Wald Test, diagnostic tests, and the Granger causality test.

\section{Unit root tests}

Table 2 shows the results of unit root test indicating that at levels null hypothesis of no unit root cannot be rejected because the value of t-statistics is fewer than the critical value and $p$-value is insignificant in Augmented Dickey-Fuller (ADF) test. This is not the case at the first difference where the t-statistic is higher than the critical values, and the $p$-values are significant, so the null hypothesis rejected at their first difference. Consequently, all the variables are stationary and integrated which means they are of the order one.

\section{Lag order selection criteria}

The model is sensitive to lag length; therefore, the study utilized lag length criteria to get the optimal lag length of VECM. After getting the results as shown in the Table 3, the optimal lag length appropriate for this is lag order 6 as suggested by all of the selection criteria.

\section{Johansen's Cointegration test}

The study then proceeds with the Johansen multivariate cointegration test has established that all the series are integrated of the same order, I (1). This cointegration test allows for 
Table 3 VAR lag order selection criteria

\begin{tabular}{|c|c|c|c|c|c|c|}
\hline Lag & $\log L$ & LR & FPE & $\mathrm{AlC}$ & SC & $\mathrm{HQ}$ \\
\hline \multicolumn{7}{|c|}{ Total BL-Equation } \\
\hline 0 & 136.1564 & NA & 0.000973 & -4.097121 & -3.996765 & -4.057524 \\
\hline 1 & 204.5579 & 128.3843 & 0.000122 & -6.171012 & -6.037204 & -6.118216 \\
\hline 2 & 220.6991 & 29.79916 & $7.68 \mathrm{e}-05$ & -6.636896 & -6.469635 & -6.570901 \\
\hline 3 & 221.1764 & 0.866461 & 7.80e-05 & -6.620812 & -6.420100 & -6.541618 \\
\hline 4 & 221.4003 & 0.399627 & 8.00e-05 & -6.596933 & -6.362769 & -6.504540 \\
\hline 5 & 226.7999 & 9.470050 & $6.99 e-05$ & -6.732305 & -6.464688 & -6.626713 \\
\hline 6 & 233.0105 & $10.70128^{a}$ & $5.95 \mathrm{e}-05^{\mathrm{a}}$ & $-6.892630^{a}$ & $-6.591561^{\mathrm{a}}$ & $-6.773839^{a}$ \\
\hline 7 & 233.0173 & 0.011590 & $6.14 \mathrm{e}-05$ & -6.862072 & -6.527551 & -6.730082 \\
\hline \multicolumn{7}{|c|}{ Private BL-Equation } \\
\hline 0 & 135.4474 & NA & 0.000995 & -4.075304 & -3.974948 & -4.035707 \\
\hline 1 & 202.9401 & 126.6786 & 0.000129 & -6.121234 & -5.987425 & -6.068438 \\
\hline 2 & 221.3178 & 33.92800 & $7.53 e-05$ & -6.655931 & -6.488671 & -6.589936 \\
\hline 3 & 222.2820 & 1.750491 & $7.54 \mathrm{e}-05$ & -6.654831 & -6.454119 & -6.575637 \\
\hline 4 & 222.3311 & 0.087683 & 7.77e-05 & -6.625574 & -6.391409 & -6.533181 \\
\hline 5 & 227.2157 & 8.566779 & $6.90 e-05$ & -6.745099 & -6.477482 & -6.639507 \\
\hline 6 & 233.4386 & $10.72255^{\mathrm{a}}$ & $5.88 \mathrm{e}-05^{\mathrm{a}}$ & $-6.905804^{\mathrm{a}}$ & $-6.604735^{a}$ & $-6.787013^{\mathrm{a}}$ \\
\hline 7 & 233.4401 & 0.002478 & $6.06 \mathrm{e}-05$ & -6.875080 & -6.540559 & -6.743090 \\
\hline \multicolumn{7}{|c|}{ Public BL-Equation } \\
\hline 0 & 103.7540 & NA & 0.002637 & -3.100123 & -2.999767 & -3.060526 \\
\hline 1 & 203.9020 & 187.9701 & 0.000125 & -6.150831 & -6.017023 & -6.098035 \\
\hline 2 & 221.2593 & 32.04414 & $7.55 e-05$ & -6.654131 & -6.486870 & -6.588136 \\
\hline 3 & 221.7571 & 0.903867 & 7.67e-05 & -6.638681 & -6.437969 & -6.559487 \\
\hline 4 & 221.9307 & 0.309765 & 7.87e-05 & -6.613253 & -6.379088 & -6.520860 \\
\hline 5 & 227.0548 & 8.986784 & $6.93 e-05$ & -6.740147 & -6.472530 & -6.634555 \\
\hline 6 & 233.8268 & $11.66865^{\mathrm{a}}$ & $5.81 e-05^{a}$ & $-6.917746^{\mathrm{a}}$ & $-6.616677^{a}$ & $-6.798955^{a}$ \\
\hline 7 & 233.8821 & 0.093747 & $5.98 \mathrm{e}-05$ & -6.888682 & -6.554160 & -6.756691 \\
\hline
\end{tabular}

aindicates lag order selected by the criterion

$L R$ Sequential modified LR test statistic (each test at $5 \%$ level)

FPE Final prediction error

AIC Akaike information criterion

SC Schwarz information criterion

HQ Hannan -Quinn information criterion

testing of the long-run equilibrium relationships (cointegration) among the series. The results obtained from the Johansen method is presented in Tables 4, 5, 6, 7, 8, and 9 shown below for three groups of variables (the group of BL equation, the group of Private BL equation and the group of Public BL equation).

The trace test tests the null hypothesis that the number of cointegrating vectors is less than or equal to $r$, where $r$ is $0,1,2$ or 3 . In each case, the null hypothesis is tested against a generic alternative. The maximum eigenvalue test, on the other hand, tests the null hypothesis $r=0$ against the alternative that $r=1, r=1$ against the alternative $r$ $=2$, and so on. The reported trace test statistic to the null hypothesis of no cointegration $(\mathrm{H} 0: \mathrm{r}=0)$ is $(55.25620)$ which is above the critical value of $(47.85613)$ at the $5 \%$ (5\%) significance level, thus, it rejects the null hypothesis of no cointegration $(r=0)$ in favour of the general alternative $r \geq 1$. On the other hand, the null hypothesis of $r \leq 1$, 
Table 4 The Trace Test (Total BL Eq.)

\begin{tabular}{|c|c|c|c|c|c|}
\hline \multicolumn{2}{|c|}{ Hypothesis } & \multirow{2}{*}{$\begin{array}{l}\text { Eigen } \\
\text { value }\end{array}$} & \multirow{2}{*}{$\begin{array}{l}\text { Trace } \\
\text { Statistic }\end{array}$} & \multirow{2}{*}{$\begin{array}{l}5 \% \\
\text { Critical } \\
\text { Value }\end{array}$} & \multirow[t]{2}{*}{ Probability } \\
\hline $\mathrm{HO}$ & $\mathrm{H} 1$ & & & & \\
\hline$r=0$ & $r \geq 1$ & 0.315004 & 55.25620 & 47.85613 & 0.0086 \\
\hline$r \leq 1$ & $r \geq 2$ & 0.241633 & 29.15060 & 29.79707 & 0.0592 \\
\hline$r \leq 2$ & $r \geq 3$ & 0.131562 & 10.06602 & 15.49471 & 0.2757 \\
\hline$r \leq 3$ & $r \geq 4$ & 0.004814 & 0.332934 & 3.841466 & 0.5639 \\
\hline
\end{tabular}

that the system contains at most one $(r \leq 1)$ cointegrating vector cannot be rejected at the $5 \%$ significance level since the reported trace statistic of (29.15060) is less than the critical value of (29.79707) at the 5\% significance level. This test concludes that there is only one cointegrating relationship among the GDP, K, L and BL. The maximum eigenvalue statistic is testing the null hypothesis of no cointegration $(\mathrm{HO}: \mathrm{r}=0)$ is accepted at the 5\% significance level as the reported maximum statistic of (26.10561) is less than the critical value at the $5 \%$ significance level. In essence, the trace test statistics reject the null hypothesis of $\mathrm{HO}: \mathrm{r}=0$ at the $5 \%$ significance level and suggest that there is only one cointegrating vector. Therefore, our quarterly data from 1996 to 2015 appears to support the existence of a long-run relationship among GDP and the other indicators $(\mathrm{K}, \mathrm{L}$ and $\mathrm{BL}$ ) based on the Johansen's cointegration procedure. This further implies that GDP maintain a stable equilibrium with $\mathrm{K}, \mathrm{L}$ and $\mathrm{BL}$ in the long-run over the entire period of the study.

By the same way and based on the Johansen's cointegration results shown in tables above, we conclude the existence of a long-run relationship among the group (GDP, K, $\mathrm{L}$ and Private $\mathrm{BL}$ ) and the group (GDP, K, L and Public BL).

\section{VAR estimation of the long-run relationship}

As mentioned before, the cointegration test examines the long-run equilibrium relationship between the variables. Now we estimate the VAR model which represents the Long-Run Relationship. The results of the VAR model estimation are presented in Table 10 for each group of variables.

The results of the BL-equation in the Table 10 show that all the coefficients are highly statistically significant at the $5 \%$ significance level. We have a positive relationship between real GDP and K (Gross Capital Formation) and L (Labour) and also BL (Total Bank Lending). The adjusted coefficient of determination (Adjusted R-squared $=0.819385$ ) indicates that the explanatory variables of $(\mathrm{K}, \mathrm{L}$ and $\mathrm{BL})$ are explaining about $82 \%$ of real GDP variability. The elasticity (coefficient) of GDP relative to K $(0.293870)$ indicates that increasing Gross Capital Formation by 1\% implies to increase the Real GDP

Table 5 The Maximum Eigenvalue Test (BL Eq.)

\begin{tabular}{|c|c|c|c|c|c|}
\hline \multicolumn{2}{|c|}{ Hypothesis } & \multirow{2}{*}{$\begin{array}{l}\text { Eigen } \\
\text { value }\end{array}$} & \multirow{2}{*}{$\begin{array}{l}\text { Max } \\
\text { eigen } \\
\text { Statistic }\end{array}$} & \multirow{2}{*}{$\begin{array}{l}5 \% \\
\text { Critical } \\
\text { Value }\end{array}$} & \multirow[t]{2}{*}{ Probability } \\
\hline $\mathrm{HO}$ & $\mathrm{H} 1$ & & & & \\
\hline$r=0$ & $r=1$ & 0.315004 & 26.10561 & 27.58434 & 0.0763 \\
\hline$r \leq 1$ & $r=2$ & 0.241633 & 19.08458 & 21.13162 & 0.0944 \\
\hline$r \leq 2$ & $r=3$ & 0.131562 & 9.733084 & 14.26460 & 0.2301 \\
\hline$r \leq 3$ & $r=4$ & 0.004814 & 0.332934 & 3.841466 & 0.5639 \\
\hline
\end{tabular}


Table 6 The Trace Test (Private BL Eq.)

\begin{tabular}{|c|c|c|c|c|c|}
\hline \multicolumn{2}{|c|}{ Hypothesis } & \multirow{2}{*}{$\begin{array}{l}\text { Eigen } \\
\text { value }\end{array}$} & \multirow{2}{*}{$\begin{array}{l}\text { Trace } \\
\text { Statistic }\end{array}$} & \multirow{2}{*}{$\begin{array}{l}5 \% \\
\text { Critical } \\
\text { Value }\end{array}$} & \multirow[t]{2}{*}{ Probability } \\
\hline $\mathrm{HO}$ & $\mathrm{H} 1$ & & & & \\
\hline$r=0^{*}$ & $r \geq 1$ & 0.314177 & 56.92152 & 47.85613 & 0.0056 \\
\hline$r \leq 1$ & $r \geq 2$ & 0.235122 & 30.89915 & 29.79707 & 0.0372 \\
\hline$r \leq 2$ & $r \geq 3$ & 0.162720 & 12.40449 & 15.49471 & 0.1385 \\
\hline$r \leq 3$ & $r \geq 4$ & 0.002177 & 0.150350 & 3.841466 & 0.6982 \\
\hline
\end{tabular}

by $0.29 \%$; the elasticity of GDP relative to BL $(0.306883)$ indicates that increasing the total Bank Lending by $1 \%$ implies to increase the Real GDP by $0.31 \%$. The elasticity of GDP relative to $\mathrm{L}(0.954095)$ indicates that increasing the Labour by $1 \%$ implies to increase the Real GDP by $0.95 \%$.

The results of the Private BL-equation in the Table 10 show that all the coefficients are highly statistically significant at the $5 \%$ significance level except $\mathrm{K}$. We have a positive relationship between real GDP and K (Gross Capital Formation) and L (Labour) and also Private BL (Private Bank Lending). The adjusted coefficient of determination (Adjusted R-squared $=0.805882)$ indicates that the explanatory variables $(\mathrm{K}, \mathrm{L}$ and Private BL) explaining about $81 \%$ of real GDP variability. The elasticity (coefficient) of GDP relative to K (0.154433) indicates that increasing Gross Capital Formation by $1 \%$ implies to increase the Real GDP by $0.15 \%$, the elasticity of GDP relative to Private BL (0.373084) indicates that increasing the total Private Bank Lending by $1 \%$ implies to increase the Real GDP by $0.37 \%$. The elasticity of GDP relative to L (1.098959) indicates that increasing Labour by $1 \%$ implies to increase the Real GDP by $1.09 \%$.

The results of the Public BL-equation in the Table 10 show that all the coefficients are highly statistically significant at the $5 \%$ significance level. We have a positive relationship between real GDP and K (Gross Capital Formation) and L (Employment) and also Public BL (Public Bank Lending). The adjusted coefficient of determination (Adjusted R-squared $=0.720541)$ indicates that the explanatory variables $(\mathrm{K}, \mathrm{L}$ and Public $\mathrm{BL})$ explaining about $72 \%$ of real GDP variability. The elasticity (coefficient) of GDP relative to K (0.731384) indicates that increasing Gross Capital Formation by $1 \%$ implies to increase the Real GDP by $0.73 \%$; the elasticiteconometricsy of GDP relative to Public BL (0.133157) indicates that increasing the total Public Bank Lending by $1 \%$ implies to increase the Real GDP by $1.33 \%$. The elasticity of GDP relative to L (0.565526) indicates that increasing Labour by $1 \%$ implies to increase the Real GDP by $0.57 \%$. Time series models are usually based on applying VAR to first differences. However, differencing eliminates valuable information about the relationship between time series data; this is where VECM is applicable in the next section (Greene 2012, p. 963).

Table 7 The Maximum Eigenvalue Test (Private BL Eq.)

\begin{tabular}{|c|c|c|c|c|c|}
\hline \multicolumn{2}{|c|}{ Hypothesis } & \multirow{2}{*}{$\begin{array}{l}\text { Eigen } \\
\text { value }\end{array}$} & \multirow{2}{*}{$\begin{array}{l}\text { Max } \\
\text { eigen } \\
\text { Statistic }\end{array}$} & \multirow{2}{*}{$\begin{array}{l}5 \% \\
\text { Critical } \\
\text { Value }\end{array}$} & \multirow[t]{2}{*}{ Probability } \\
\hline $\mathrm{HO}$ & $\mathrm{H} 1$ & & & & \\
\hline$r=0^{*}$ & $r=1$ & 0.314177 & 26.02238 & 27.58434 & 0.0781 \\
\hline$r \leq 1$ & $r=2$ & 0.235122 & 18.49465 & 21.13162 & 0.1124 \\
\hline$r \leq 2$ & $r=3$ & 0.162720 & 12.25414 & 14.26460 & 0.1015 \\
\hline$r \leq 3$ & $r=4$ & 0.002177 & 0.150350 & 3.841466 & 0.6982 \\
\hline
\end{tabular}


Table 8 The Trace Test (Public BL Eq.)

\begin{tabular}{|c|c|c|c|c|c|}
\hline \multicolumn{2}{|c|}{ Hypothesis } & \multirow{2}{*}{$\begin{array}{l}\text { Eigen } \\
\text { value }\end{array}$} & \multirow{2}{*}{$\begin{array}{l}\text { Trace } \\
\text { Statistic }\end{array}$} & \multirow{2}{*}{$\begin{array}{l}5 \% \\
\text { Critical } \\
\text { Value }\end{array}$} & \multirow[t]{2}{*}{ Probability } \\
\hline $\mathrm{HO}$ & $\mathrm{H} 1$ & & & & \\
\hline$r=0^{*}$ & $r \geq 1$ & 0.357418 & 61.71907 & 47.85613 & 0.0015 \\
\hline$r \leq 1$ & $r \geq 2$ & 0.240828 & 31.20304 & 29.79707 & 0.0342 \\
\hline$r \leq 2$ & $r \geq 3$ & 0.161745 & 12.19168 & 15.49471 & 0.1480 \\
\hline$r \leq 3$ & $r \geq 4$ & 0.000258 & 0.017824 & 3.841466 & 0.8937 \\
\hline
\end{tabular}

\section{Vector error correction model (VECM)}

Table 11 states the results of VECM. The VECM with BL, the first coefficient error correction term is positive with a value of 0.111775 , and it is insignificant with a $p$-value of 0.5797 that means there exist not long-run causality, but it is not running from the capital, labour and bank lending to the economic growth. The value of R-squared states that variables included in VECM explain almost $47 \%$ of the response in the dependent variable economic growth.

The VECM with Private BL, the first coefficient of error correction term is negative with a value of -0.25876 , and it is insignificant with a $p$-value of 0.2545 that means there exist not long-run causality running from the capital, labour and private bank lending to the economic growth, but it is insignificant. The value of R-squared states that variables included in VECM explain almost $48 \%$ of the response in the dependent variable economic growth.

Finally, the VECM with Public BL, the first coefficient error correction term is positive with a value of 0.10208 , and it is insignificant with a p-value of 0.6836 , meaning that there not exist a long-run causality, and it is not running from the capital, labour and public bank lending to the economic growth. The value of R-squared states that variables included in VECM explain almost $46.5 \%$ of the response in the dependent variable economic growth.

Given the results of this test, the error correction term for the variable Private $\mathrm{BL}$ holds the correct sign, i.e. negative in at least one direction, but the relationship is not significant. In contrast, the error correction term shows that the variable $\mathrm{BL}$ and the variable Public BL hold not the correct sign, i.e. positive in at least one direction, and the relationship is not significant. Accordingly, the results the coefficients of the error correction term which measure the speed of adjustment of the variable BL, Private BL, Public BL are unlikely to be at the equilibrium in the long-run, as the only variable with the correct sign is the variable Private $\mathrm{BL}$, but the relationship regarding this variable is insignificant as stated above.

Table 9 The Maximum Eigenvalue Test (Public BL Eq.)

\begin{tabular}{|c|c|c|c|c|c|}
\hline \multicolumn{2}{|c|}{ Hypothesis } & \multirow{2}{*}{$\begin{array}{l}\text { Eigen } \\
\text { value }\end{array}$} & \multirow{2}{*}{$\begin{array}{l}\text { Max } \\
\text { eigen } \\
\text { Statistic }\end{array}$} & \multirow{2}{*}{$\begin{array}{l}5 \% \\
\text { Critical } \\
\text { Value }\end{array}$} & \multirow[t]{2}{*}{ Probability } \\
\hline $\mathrm{HO}$ & $\mathrm{H} 1$ & & & & \\
\hline$r=0^{*}$ & $r=1$ & 0.357418 & 30.51603 & 27.58434 & 0.0204 \\
\hline$r \leq 1$ & $r=2$ & 0.240828 & 19.01136 & 21.13162 & 0.0965 \\
\hline$r \leq 2$ & $r=3$ & 0.161745 & 12.17385 & 14.26460 & 0.1043 \\
\hline$r \leq 3$ & $r=4$ & 0.000258 & 0.017824 & 3.841466 & 0.8937 \\
\hline
\end{tabular}


Table $10 \mathrm{VAR}$ Results

\begin{tabular}{|c|c|c|c|c|}
\hline \multicolumn{5}{|c|}{ BL Equation: InGDP $=f(\operatorname{LnK}, \mathrm{LnL}, \mathrm{LnBL})$} \\
\hline Repressors & Coefficients & Std.Error & t-Statistics & Prob. \\
\hline LnK & 0.293870 & 0.086220 & 3.408375 & 0.0011 \\
\hline LnL & 0.954095 & 0.130703 & 7.299699 & 0.0000 \\
\hline LnBL & 0.306883 & 0.020504 & 14.96697 & 0.0000 \\
\hline R-squared & Adjusted R-squared & Sum sq. resides & S.E. of equation & F-statistic \\
\hline 0.824473 & 0.819385 & 0.116309 & 0.041056 & 162.0509 \\
\hline Log-likelihood & Akaike AIC & Schwarz SC & Mean dependent & S.D. dependent \\
\hline 129.2507 & -3.506963 & -3.412102 & 3.660591 & 0.096606 \\
\hline \multicolumn{5}{|c|}{ Private $\mathrm{BL}$ Equation: $\operatorname{lnGDP}=f(\mathrm{LnK}, \mathrm{LnL}, \mathrm{Ln}$ Private $\mathrm{BL})$} \\
\hline Regressors & Coefficients & Std.Error & t-Statistics & Prob. \\
\hline LnK & 0.154433 & 0.095207 & 1.622077 & 0.1093 \\
\hline LnL & 1.098959 & 0.139220 & 7.893690 & 0.0000 \\
\hline Ln Private $B L$ & 0.373084 & 0.026145 & 14.26982 & 0.0000 \\
\hline R-squared & Adjusted R-squared & Sum sq. resides & S.E. of equation & F-statistic \\
\hline 0.811350 & 0.805882 & 0.125004 & 0.042564 & 148.3782 \\
\hline Log-likelihood & Akaike AIC & Schwarz SC & Mean dependent & S.D. dependent \\
\hline 126.6551 & -3.434863 & -3.340002 & 3.660591 & 0.096606 \\
\hline \multicolumn{5}{|c|}{ Public BL Equation: In GDP $=f(\operatorname{Ln} K, \operatorname{Ln} L, L n$ Public $B L)$} \\
\hline Repressors & Coefficients & Std.Error & t-Statistics & Prob. \\
\hline Ln K & 0.731384 & 0.093873 & 7.791194 & 0.0000 \\
\hline $\operatorname{Ln} \mathrm{L}$ & 0.565526 & 0.155704 & 3.632054 & 0.0005 \\
\hline Ln Public BL & 0.133157 & 0.012137 & 10.97146 & 0.0000 \\
\hline R-squared & Adjusted R-squared & Sum sq. resides & S.E. of equation & F-statistic \\
\hline 0.728413 & 0.720541 & 0.179961 & 0.051070 & 92.53103 \\
\hline Log likelihood & Akaike AIC & Schwarz SC & Mean dependent & S.D. dependent \\
\hline 113.5370 & -3.070474 & -2.975612 & 3.660591 & 0.096606 \\
\hline
\end{tabular}

On the other hand, the results of R-squared for VECM are different from VAR; this is due to VAR is applied to first differences, so that the results of VECM is more applicable and reliable as explained by the end of the above section.

On the other hand, the Wald test in Table 12 shows the procedure can be used to test the existence of the short run causality. The VECM with BL, the F- Statistics and chi-square statistics are insignificant with $p$-values $>0.05$ that means there is no short-run causality between the variables under consideration. As shown from the Table 12, we got the same results to the VECM with Private BL and the VECM with Public BL.

In order to test the validity of the model and to ascertain any discrepancies, the study applied diagnostic tests in Table 13 for serial correlation, heteroscedasticity and normality. The results show that the model is free from the problem of serial correlation at $5 \%$ level of significance. There are also no issues of heteroscedasticity and normality in the model. The results show the overall validity and reliability of the model.

\section{Granger causality test}

The study now turns to examine the Granger-causality relationships between the variables under study. Granger-causality may have more to do with prediction, than with causation in the usual sense. It suggests that while the past can cause or predict the future, the 
Table 11 VECM results

\begin{tabular}{|c|c|c|c|c|}
\hline & Coefficient & Std. Error & t-Statistic & Prob. \\
\hline \multicolumn{5}{|l|}{ VECM with $B L$} \\
\hline$C(1)$ & 0.111775 & 0.200075 & 0.558664 & 0.5797 \\
\hline R-squared & 0.470935 & \multicolumn{2}{|c|}{ Mean dependent var } & -0.00021 \\
\hline Adjusted R-squared & 0.122866 & \multicolumn{2}{|c|}{ S.D. dependent var } & 0.00903 \\
\hline S.E. of regression & 0.008457 & \multicolumn{2}{|c|}{ Akaike info criterion } & -6.41648 \\
\hline Sum squared reside & 0.002718 & \multicolumn{2}{|c|}{ Schwarz criterion } & -5.53943 \\
\hline Log likelihood & 231.3273 & \multicolumn{2}{|c|}{ Hannan -Quinn criter. } & -6.07097 \\
\hline F-statistic & 1.352993 & \multicolumn{2}{|c|}{ Durbin-Watson stat } & 1.990608 \\
\hline Prob (F-statistic) & 0.196087 & & & \\
\hline \multicolumn{5}{|l|}{ VECM with Private BL } \\
\hline$C(1)$ & -0.25876 & 0.223641 & -1.15701 & 0.2545 \\
\hline R-squared & 0.479734 & \multicolumn{2}{|c|}{ Mean dependent var } & -0.00021 \\
\hline Adjusted R-squared & 0.137453 & \multicolumn{2}{|c|}{ S.D. dependent var } & 0.00903 \\
\hline S.E. of regression & 0.008386 & \multicolumn{2}{|c|}{ Akaike info criterion } & -6.43325 \\
\hline Sum squared reside & 0.002672 & \multicolumn{2}{|c|}{ Schwarz criterion } & -5.5562 \\
\hline Log likelihood & 231.864 & \multicolumn{2}{|c|}{ Hannan -Quinn criter. } & -6.08774 \\
\hline F-statistic & 1.401581 & \multicolumn{2}{|c|}{ Durbin-Watson stat } & 2.047383 \\
\hline Prob (F-statistic) & 0.170216 & & & \\
\hline \multicolumn{5}{|l|}{ VECM with Public BL } \\
\hline$C(1)$ & 0.10208 & 0.248553 & 0.410696 & 0.6836 \\
\hline R-squared & 0.465124 & \multicolumn{2}{|c|}{ Mean dependent var } & -0.00021 \\
\hline Adjusted R-squared & 0.113232 & \multicolumn{2}{|c|}{ S.D. dependent var } & 0.00903 \\
\hline S.E. of regression & 0.008503 & \multicolumn{2}{|c|}{ Akaike info criterion } & -6.40556 \\
\hline Sum squared reside & 0.002748 & \multicolumn{2}{|c|}{ Schwarz criterion } & -5.52851 \\
\hline Log likelihood & 230.9778 & \multicolumn{2}{|c|}{ Hannan -Quinn criter. } & -6.06004 \\
\hline F-statistic & 1.321782 & \multicolumn{2}{|c|}{ Durbin-Watson stat } & 1.98956 \\
\hline Prob (F-statistic) & 0.214425 & & & \\
\hline
\end{tabular}

future cannot cause or predict the past. Table 14 gives a summary of the results of the Granger Causality Test over the entire period of study; the findings indicate just a unidirectional Granger causal relationship from the economic growth (GDP) to Bank Lending and a unidirectional Granger causal relationship from the economic growth (GDP) to Public Bank Lending, this result is in contradiction with other previous research (Caporalea et al. 2016), (Cecchetti and Kharroubi 2012).

Accordingly, we conclude that the past values of GDP can be used to predict both BL and Public BL more accurately than only using the past values of BL or Public BL, but the opposite direction is not right. For this test, we used the first log difference of the variables because the Granger-Causality test works on the assumption of stationary variables and as already discussed, these first log differences are stationary.

\section{Discussion of results}

The primary objective of this study is to determine the impact of bank lending on economic growth (Real GDP) in Palestine and identify the causality relationship between 
Table 12 Wald Test

\begin{tabular}{lllll}
\hline BL Equation/Lag variables & Test Statistic & Value & df & Probability \\
K & F-statistic & 0.877437 & $(6,39)$ & 0.5203 \\
& Chi-square & 5.264624 & 6 & 0.5103 \\
L & F-statistic & 1.595843 & $(6,39)$ & 0.1743 \\
& Chi-square & 9.575057 & 6 & 0.1437 \\
BL & F-statistic & 0.465072 & $(6,39)$ & 0.8298 \\
& Chi-square & 2.790431 & 6 & 0.8347 \\
Private BL Equation/Lag variables & Test Statistic & Value & $\mathrm{df}$ & Probability \\
K & F-statistic & 0.916487 & $(6,39)$ & 0.4935 \\
& Chi-square & 5.498922 & 6 & 0.4816 \\
L & F-statistic & 0.980623 & $(6,39)$ & 0.4514 \\
& Chi-square & 5.883738 & 6 & 0.4363 \\
Private BL & F-statistic & 0.291091 & $(6,39)$ & 0.9376 \\
& Chi-square & 1.746548 & 6 & 0.9415 \\
Public BL Equation/Lag variables & Test Statistic & Value & $\mathrm{df}$ & Probability \\
K & F-statistic & 1.823439 & $(6,39)$ & 0.1197 \\
& Chi-square & 10.94063 & 6 & 0.0902 \\
L & F-statistic & 1.155443 & $(6,39)$ & 0.3496 \\
& Chi-square & 6.932659 & 6 & 0.3271 \\
& F-statistic & 1.271456 & $(6,39)$ & 0.2928 \\
& Chi-square & 7.628738 & 6 & 0.2666 \\
\hline
\end{tabular}

economic growth as a dependent variable with three explanatory variables of total bank lending (Total BL), gross capital formation (K), and labor (L) over the period (1996-2015). Investigating this empirical relationship is likely to provide policy recommendations to Palestinian policymakers so that they can significantly make use of this for enhancing the role of bank lending in Palestine economic growth. In addition, the study results provide background information to researchers in this field.

As aforesaid, the main empirical findings of the econometric analysis show that the explanatory variables (K, L and Total $\mathrm{BL}$ ) explaining about $82 \%$ of real GDP variability (Increasing Gross Capital Formation by 1\% implies to increase the Real GDP by $0.29 \%$. - Increasing the Total Bank Lending by $1 \%$ implies to increase the Real GDP by $0.31 \%$. - Increasing Labor by $1 \%$ implies to increase the Real GDP by $0.95 \%)$. The causality relationship between GDP and total bank lending runs from real GDP to total bank lending, which is unlikely to stimulate economic growth in Palestine.

The explanatory variables (K, L and Private BL) explain about $81 \%$ of real GDP variability. (Increasing Gross Capital Formation by $1 \%$ implies to increase the Real GDP by $0.15 \%$ - Increasing the Private Bank Lending by $1 \%$ implies to increase the Real

Table 13 Residual Diagnostics Tests

\begin{tabular}{|c|c|c|c|c|c|c|}
\hline \multirow[t]{2}{*}{ Diagnostic } & \multicolumn{2}{|l|}{ BL Equation } & \multicolumn{2}{|c|}{ Private BL Equation } & \multicolumn{2}{|c|}{ Public BL Equation } \\
\hline & Test Statistic & P-Value & Test Statistic & P-Value & Test Statistic & P-Value \\
\hline Serial correlation & 0.02635 & 0.9791 & 1.044369 & 0.3033 & 0.08365 & 0.9338 \\
\hline Normality & 3.23055 & 0.19883 & 3.73843 & 0.154245 & 2.961250 & 0.227459 \\
\hline Hetroscedasticity & 0.68679 & 0.4973 & 0.292674 & 0.7717 & 0.03863 & 0.9694 \\
\hline
\end{tabular}


Table 14 The results of the Granger Causality Test

\begin{tabular}{llll}
\hline The direction of Granger Causality & $\begin{array}{l}\text { Total BL Equation } \\
\text { Decision }\end{array}$ & $\begin{array}{l}\text { Private BL Equation } \\
\text { Decision }\end{array}$ & $\begin{array}{l}\text { Public BL Equation } \\
\text { Decision }\end{array}$ \\
\hline$K \Rightarrow G D P$ & No Causality & No Causality & No Causality \\
$G D P \Rightarrow K$ & No Causality & No Causality & No Causality \\
$L \Rightarrow G D P$ & No Causality & No Causality & No Causality \\
$G D P \Rightarrow L$ & No Causality & No Causality & No Causality \\
$B L \Rightarrow G D P$ & No Causality & No Causality & No Causality \\
$G D P \Rightarrow B L$ & Causality & No Causality & Causality \\
$L \Rightarrow K$ & No Causality & No Causality & No Causality \\
$K \Leftrightarrow L$ & No Causality & No Causality & No Causality \\
$B L \Rightarrow K$ & No Causality & No Causality & No Causality \\
$K \Rightarrow B L$ & No Causality & No Causality & No Causality \\
$B L ~$ & No Causality & No Causality & No Causality \\
$L \Rightarrow B L$ & No Causality & No Causality & No Causality \\
\hline
\end{tabular}

GDP by $0.37 \%$ - Increasing Labour by $1 \%$ implies to increase the real GDP by $0.10 \%$. There is no causal relationship between real GDP and private bank lending. As a result, the volume of loan actually given to investors is insignificant, and could not add a meaningful contribution to the real GDP, may be attributed to the fact that banks exhibit apathy in lending to the production sector of the economy due to a high level of risk involved.

The explanatory variables ( $\mathrm{K}, \mathrm{L}$ and Public $\mathrm{BL}$ ) explain $72 \%$ of real GDP variability. (Increasing Gross Capital Formation by $1 \%$ implies to increase the Real GDP by $0.73 \%$ - Increasing the Public Bank Lending by 1\% implies to increase the Real GDP by $1.33 \%$ - Increasing Labour by $1 \%$ implies to increase the real GDP by $0.57 \%$. The causality relationship between real GDP and public bank lending runs from real GDP to public bank lending, which is unlikely to promote economic growth.

With reference to the above analysis of the empirical study results, there is clue evidence from the study does not support the view that bank lending promotes economic growth in Palestine. Developing countries have their own socioeconomic, political and institutional history which makes them different from each other as well as their developed counterparts, and thus the existence of reverse causality between finance and growth (Carby et al. 2012). On the other hand, the results show that there are positive and significant relationship between bank lending and economic growth in the long-run, this finding supports the work carried out by (Nwaru and Okorontah 2014), (Owolabi et al. 2013), (Ndlovu 2013), (Sami 2013), (Carby et al. 2012), (Simwaka 2012) and (Liang and Huang 2011). This relationship, however, does not seem to hold in the short-run; this finding supports the work carried out by (Nasir et al. 2014), and (Ekone 2010).

By appealing to Granger causality tests, however, it is found that economic growth drives bank lending, but the opposite is not exact. Such a result reveals that bank lending doesn't have a significant role in economic growth, although real GDP causes bank lending in Palestine. The lack of causality of bank lending on economic growth could be attributed to the less developed banking sector in Palestine. There is a need to put in place policies to support the development of growth-enhancing banking sector. For banking development to have a positive effect on economic growth, it is necessary 
that the expansion of the banking system be accompanied by an increase in the flow of funds towards productive investment activities. In contrast to this result, the results imply that economic growth plays a vital role in the development of the banking sector in Palestine. In other words, bank landing can significantly be enhanced by real GDP, meaning that promoting economic growth is necessary for supporting the Palestinian banking sector.

\section{Conclusions and policy implications}

\section{Conclusions}

This study examines the impact of bank lending on economic growth in Palestine during the period (Q1 1996 - Q4 2015) and identifies the mechanism through, which bank lending affects economic growth. This study uses a multivariate co-integration method by Johansen and Juselius (1990). Following a detailed time series analysis, the findings reveal that bank lending doesn't drive economic growth in Palestine. Accordingly, we conclude that the sustainable development goal 8 (i.e., Promote sustained, inclusive and sustainable economic growth, full and productive employment and decent work for all.) is likely to be not reachable in Palestine for the time being. Given this conclusion, policymakers should pay serious attention to bank lending in Palestine, so it should be restructured and redirected for productive and sustainable economic activities rather than unproductive activities and consumer loans, this may play a vital role in economic growth and meeting the sustainable development goal 8 .

It was also discovered that causality based on VAR-VECM and runs from GDP to bank lending. Based on the study results shown above, we conclude that it is unlikely to be at the equilibrium level in the long-run, so that the insignificant contribution of bank lending to GDP may be attributed to the fact that banks exhibit apathy in lending to the production sector of the economy due to the high level of risk involved. In addition, this indicates the existence of economic distortion in bank ending, so that policymakers are advised to change their economic policies of bank lending to real investment instead of consumer loans as discussed above.

\section{Policy implications}

According to the findings of this study, a number of policy issues stand out clearly. The primary empirical evidence reveals that bank lending doesn't cause economic growth, but economic growth causes bank lending, this empirical result is likely to be in contradiction with economic theory and other previous research as presented above.

However, three important policy implications for conducting economic and financial reforms are necessary to take into consideration in Palestine, with particular attention being paid to the banking sector. Those are: (1) the Palestinian monetary authorities must be oriented towards not only the promotion of manufacturing output growth but also towards the continuing banking development processes that focus on performance of the real sector generally, and the manufacturing sector in particular; (2) financial reforms and policies should focus on how to narrow the gap between savings and lending rates, and banks should also be encouraged to lend to the entire economy as against favouring some specific sectors; and (3) the government should also avoid excessive deficit and borrowing from the private sector, which proves to be crowding-out private investment. 
Abbreviations

ADF: Augmented Dickey-Fuller; AIC: Akaike Information Criterion; ARDL: Autoregressive Distributed Lag; BK: Bank Lending; GDP: Gross Domestic Product; K: Gross Capital Formation; L: Labor; OLS: Ordinary Least Squares; PCBS: Palestinian Central Bureau of Statistics; PLA: Palestinian Local Authority; PMA: Palestine Monetary Authority; PNA: Palestinian National Authority; SBC: Schwartz Bayesian Criterion; VAR: Vector Autoregressive; VECM: Vector Error Correction Model

\section{Acknowledgements}

We thank our colleagues from Al-Quds University and internationally for assistance and their comments that significantly improved the manuscript.

\section{Funding}

Authors declare that they have no funding for this research.

\section{Availability of data and materials}

Data and materials used in this paper were collected from the Palestine Monetary Authority (PMA) and Palestinian Central Bureau of Statistics (PCBS).

\section{Authors' contributions}

The two co-authors have made significant contribution jointly and are in agreement with the contents of this paper.

\section{Competing interests}

The authors declare that they have no competing interests.

\section{Publisher's Note}

Springer Nature remains neutral with regard to jurisdictional claims in published maps and institutional affiliations.

\section{Author details}

${ }^{1}$ Faculty of Business and Economics, Al-Quds University - Abu Dis Campus, P. O. Box 51000, Jerusalem, Palestine.

${ }^{2}$ College of Graduate Studies and Academic Research, Hebron University, Hebron, Palestine.

\section{Received: 20 December 2017 Accepted: 11 March 2019}

Published online: 18 March 2019

\section{References}

Aliero HM (2013) Private sector credit and economic growth Nexus in Nigeria. Mediterr J Soc Sci 4(1):83-90

Awad I, Al-Ewesat A (2017) Volatility Persistence in Palestine Exchange Bulls and Bears: An Econometric Analysis of Time Series Data. Rev Econ Finance 9:83-97

Awad I, Hallam A, Alialhuseen M (2017) Testing the validity of Okun's rule of thumb across Palestine and Israel. Rev Appl Econ 13:1-2

Awe, O. O. (2012). On pairwise granger causality modelling and econometric analysis of selected economic indicators. Interstat Statjournals

Banu (Butiuc), Mădălina I (2013) The impact of credit on economic growth in the global crisis context. Procedia Econ Finance 6:25-30

Bashir Z (2003) Effects of economic reforms on agriculture and agricultural trade in India and Pakistan. Macquarie University (division of economic and financial studies, Department of Economics), pp 101-119

Ben-Naceur, E. A., De Groen, W. P., \& Ayadi, R. (2013). Financial development, Bank efficiency and economic growth across the Mediterranean. Retrieved 1 5, 2014, from www.medpro-foresight.eu

Caporalea GM, Collic SD, Robe Salvoc RD, Lopezc JS (2016) Local banking and local economic growth in Italy: some panel evidence. Appl Econ 48(28):2665-2674

Carby Y, Craigwell R, Wright A, Wood A (2012) Finance and growth causality: a test of the Patrick's stage-of-development hypothesis. Int J Bus Soc Sci 3(21):129-139

Cecchetti SG, Kharroubi E (2012) Reassessing the impact of finance on growth. BIS working papers, n. 381

Egbetunde T, Akinlo AE (2010) Financial development and economic growth: the experience of 10 sub-Saharan African countries revisited. Rev Finance Banking 2(1):17-28

Ekone MS (2010) Money supply - economic growth Nexus in Nigeria. Kamla-Raj, J Soc Sci 22(3):199-204

Engle R and Granger C (1987) Cointegration and Error Correction: Representation, Estimation and Testing. Econometrica, 55 : 251-276.

European Economic Forecast Winter (2018) (Interim), European Commission, ISSN 2443-8014 (online)

Ferguson N (2008) The ascent of money a financial history of the world. 10014: The Penguin Press, New York

Fosu SB (2013) Financial Development and Economic Growth in Africa: A Dynamic Causal Relationship. University of New Hampshire, pp 45-53, MA thesis

Gonzalo J (1994) Five alternative methods of estimating long-run equilibrium relationships. J Econ 60(1-2):203-233

Granger C (1981) Some properties of time series data and their use in econometric model specification. J Econ 16(1):121-130

Greene W (2012) Econometric analysis, 7th edn. Prentice Hall, Upper Saddle River

Guttentag MJ (2011) Financial development and economic growth: the Bolivian case. The University of Manchester Hargreaves C (1994) A review of methods of estimating Cointegrating relationships. Oxford University Press Inc., New York Johansen S (1988) Statistical analysis of cointegration vectors. J Econ Dyn Control 12:231-254

Johansen S, Juselius K (1990) Maximum likelihood estimation and inferences on cointegration with applications to the demand for money. Oxf Bull Econ Stat 52:169-210 
Jordaan, A. C. (2010). Financial sector development and economic growth in Botswana: a causality analysis. Retrieved 2014, the University of Pretoria

Labour Force Survey (2014) Annual Report: 2014. State of Palestine Palestinian Central Bureau of Statistics, Ramallah

Liang, F., \& Huang, W. (2011). The relationship between money supply and the GDP of the United States. Retrieved 2014, from Hong Kong Baptist University, www.hkbu.edu.hk/eng

Lucas R (1988) On the mechanics of economic development. J Monet Econ 22(1):3-42

Maduka AC, Onwuka KO (2013) Financial market structure and economic growth: evidence from Nigeria data. Asian Econ Financ Rev 3(1):75-98

Masih M, Al-Elg A, Madani H (2010) Causality between financial development and economic growth: an application of vector error correction and variance decomposition methods to Saudi Arabia. Appl Econ 41(13):1691-1699

McKinnon RI (1973) Money and Capital in Economic Development. The Brookings Institution, Washington

Murty KS, Sailaja K, Demissie WM (2012) The long-run impact of Bank credit on economic growth in Ethiopia: evidence from the Johansen's multivariate Cointegration approach. Eur J Bus Manag 4(14):20-33

Nasir NM, Ali N, Khokhar I (2014) Economic growth, financial depth and lending rate Nexus: a case of oil dependent economy. Int J Financ Research 5(2):59-68

Ndlovu G (2013) Financial sector development and economic growth: evidence from Zimbabwe. Int J Econ Financ Issues 3(2):435-446

Nwaru NM, Okorontah CF (2014) Banks' credit as an instrument of economic growth in Nigeria. Int J Bus Law Res 5(2):102-110 Owolabi SA, Olanrewaju GO, Okwu AT (2013) The causality between banking sector reforms and sectoral output growth: empirical evidence. Unique J Bus Manag Res 1(3):42-48

Palestine Monetary Authority (PMA), P. M. (2016). StatisticsTime series data. Retrieved 2016, http://www.pma.ps/

Palestinian Central Bureau of Statistics (PCBS) (2016): http://www.pcbs.gov.ps/site/lang_en/1/default.aspx

Parkin M (2012) Economics, p. 37, 10th edn. Addison-Wesley, Ontario

Precious C, Palesa MK (2014) Impact of Monetary policy on economic growth. Mediterr J Soc Sci 5(15):76-84

Sami J (2013) Remittances, banking sector development and economic growth in Fiji. Int J Econ Financ Issues 392:503-511

Schumpeter JA (1939) Business cycles: a theoretical, Historical, and Statistical Analysis of the Capitalist Process, pp 1-20

Schumpeter JA (1954) History of economic analysis. Oxford University Press, New York, p 111

Shaw E (1973) Financial deepening in economic development. Oxford University Press, New York

Simwaka KT (2012) Financial development and economic growth in Malawi: an empirical analysis. Banks and Bank Syst 7(3):85-96

Slavin SL (2009) Macroeconomics, ninth edition. 10020: McGraw-Hill Companies, Inc, New York, p 390

Smith MP (2012) Economic development. Addison-Wesley, Boston

Taha Z, Anis O, Hassen S (2013) Banking intermediation and economic growth: some evidence from MENA countries. Adv Manag Appl Econ 3(4):51-57

Timsina N, Pradhan RS (2016) Effects of Bank lending on economic growth in Nepal. J Adv Acad Res 3:53-75

Yazdi SK, Khanalizadeh B (2013) The financial development and agriculture growth in Iran: ARDL approach. Recent advances in energy, environment and financial planning, ISBN: 978-960-474-400-8, pp 335-342

\section{Submit your manuscript to a SpringerOpen ${ }^{\circ}$ journal and benefit from:}

- Convenient online submission

Rigorous peer review

- Open access: articles freely available online

- High visibility within the field

- Retaining the copyright to your article

Submit your next manuscript at $\boldsymbol{\nabla}$ springeropen.com 